\title{
Performance Enhancement of R.C. Beams with Large Web Openings by Using Reactive Powder Composite: An Experimental Study
}

\author{
Nidaa Qassim Jassim \\ Husain Khalaf Jarallah \\ Department of Civil Engineering, Faculty of Engineering, Mustansiriyah University \\ Baghdad, IRAQ \\ nidaaqj@gmail.com \\ Received: 15 -Nov.-2017 \\ khalfdce@uomustansiriyah.edu.iq \\ Revised: 07-Jan.-2018 Accepted: 27-June-2018
}

http://doi.org/10.29194/NJES.21030405

\begin{abstract}
In this paper an experimental works conducted to study the behavior of R.C. beam with large web opening at different locations and fortified with reactive powder composite (RPC) at the extreme tension zone (bottom edge of opening) and/or extreme compression zone (Top edge of opening).The experimental study is investigate the behavior of twelve beams and study the ability of using normal strength concrete together with RPC in the same section to exploit the advantages of these two materials in optimal way. The main variables are RPC layers locations in tension zone and/or in compression zone and the locations of openings. The ultimate loads, load mid-span deflection behavior and strain for steel and concrete were discussed. The experimental results showed that the ultimate strength was decreases with increasing number of opening about $4 \%$ for beams with two openings located in shear zone and $21 \%$ for beams with three openings, thus indicating that the stiffness decreases accordingly. The using RPC layers effectively enhanced performance of hybrid beams when compared with using the normal strength concrete layers only. The using RPC layers in compression and tension zones increased the ultimate load about $47 \%$ for beams with two opening located in shear zone, when using RPC in the tension zone and normal strength concrete in the compression zone the ultimate flexural load and ultimate deflection increase little compared with normal concrete.
\end{abstract}

Keywords: Reactive Powder Composite, Openings, Layers, Deflection, Strain, Curvature, Cracks, Hybrid Section, Strength.

\section{Introduction}

Utility pipes and ducts are necessary to accommodate essential services in a building. The types of services include air-conditioning, power supply, telephone line, computer network, sewerage and water supply. It has been practiced that pipes and ducts are usually hanged below the floor beams, and covered by a suspended ceiling for its aesthetic purpose. These openings can be of different shapes and sizes as circular, square or rectangular [1]. The presence of an opening in the web of a reinforced concrete beam leads to many problems in the beam behavior such as reduction in the beam stiffness, excessive cracking, excessive deflection and reduction in the beam strength $[2,3]$. Furthermore, sudden change in the dimension of cross section of the beam leads to high stress concentration at the corners of opening that may lead to cracking unacceptable from aesthetic and durability viewpoints. The reduced stiffness of the beam may also give rise to excessive deflection under service load and result in a considerable redistribution of internal forces and moments in a continuous beam. Mansur et al. [6], Aykac et al. [7] and Egriboz [8] investigated the influence of multiple web openings along the length of an r.c. beam on its flexural behavior. Tanijaya and Hardjito [9] studied the influence of openings on the response of hybrid reinforced concrete T-beams, with the beams subjected to cyclic load applied at mid-span. Abdallah et al. [10], Allam [2] and Pimanmas [11] used carbon zone reinforced polymer (CFRP) sheets to strengthen the opening region.

In order to improve the ductility of beams with large web opening the reactive powder composite (RPC) was used in this study at different layers. RPC is now more generally described as ultra-high performance concrete (UHPC) [4].The addition of zones to UHPC further improves tensile cracking resistance, post cracking strength, ductility and energy absorption capacity [5] .

Ismael, M. A [12] studied the flexural behavior of eleven ultra-high performance conventionally reinforced concrete beams containing hooked and crimped steel zones. Raj and Jeenu [13] and Mohammed [14] investigated the flexural behavior (strength and deformation characteristics) of hybrid rectangular beams combining conventional concrete (CC) and RPC.

A few research about investigated conduct for RC beams having openings and fortified with RPC. Therefore, the aim of this research is investigate the amount of the effect of the presence of large opening in the web of reinforced concrete beams fortified with RPC layers and the evaluation of these effects on the ultimate strength, mode failure, strain and the behavior of these beams. The main 
factors in this study is the number of web openings along the span and RPC layer locations. The results of ultimate strength, load-deflection, failures modes, load - strain, neutral axis depth and curvature will be discussing.

\section{Experimental Program \\ 2.1 Materials and Mix Proportion}

RPC used in this study consists of Ordinary Portland cement, silica fume, glass sand, steel zones and Superplasticizer commercially named Flocrete PC 260. While the normal concrete (NC) consists of Ordinary Portland cement, sand and crushed gravel were used. The specified mix proportions of RPC and concrete are tabulated in Table 1. Laboratory tests were carried out in the laboratory of the Faculty of Engineering; Mustansiriyah University. Tests results of mechanical properties of NC and RPC are given in Table. 2. The characteristic yield strength of tested bar steel reinforcement was $470.8 \mathrm{MPa}$ for nominal diameter $(\phi 8 \mathrm{~mm})$ and $390 \mathrm{MPa}$ for nominal diameter $(\phi 4 \mathrm{~mm})$, the results conform to the limitation of the specification ASTM-A615[15] and ASTM -A496 [16]. The time period between the placing of the two layers was about (55-60) minutes where the top surface of the bottom layer was left rough to ensure good interaction between the two layers. This time was obtained by conducting an initial setting time experiment for RPC, the test was performed according to ASTM C191-13[17] by using Vicat Needle and the measured setting time was about (45) minutes for Portland cement.

Table 1: Mix Proportions of NC and RPC

\begin{tabular}{|c|c|c|}
\hline Concrete Type & NSC & RPC \\
\hline $\begin{array}{c}\text { Cement (C) } \\
\left(\mathrm{kg} / \mathrm{m}^{3}\right)\end{array}$ & 400 & 1000 \\
\hline Sand $(\mathrm{S})\left(\mathrm{kg} / \mathrm{m}^{3}\right)$ & 600 & 1000 \\
\hline $\begin{array}{l}\text { Gravel (G) } \\
\left(\mathrm{kg} / \mathrm{m}^{3}\right)\end{array}$ & 1200 & - \\
\hline $\begin{array}{c}\text { Silica Fume } \\
(\mathrm{SF} \%)^{*}\left(\mathrm{~kg} / \mathrm{m}^{3}\right)\end{array}$ & - & 250 \\
\hline $\begin{array}{c}\text { Super- } \\
\text { plasticizer(SP) } \\
\text { PC260\% }\left(\mathrm{kg} / \mathrm{m}^{3}\right)\end{array}$ & - & 75 \\
\hline $\begin{array}{c}\text { Water }(\mathrm{W}) \\
\left(\mathrm{kg} / \mathrm{m}^{3}\right)\end{array}$ & 180 & 200 \\
\hline $\begin{array}{l}\text { Water/ cement } \\
\text { ratio W/C }\end{array}$ & 0.45 & 0.2 \\
\hline $\begin{array}{l}\text { Steel fiber } \\
\left(\mathrm{kg} / \mathrm{m}^{3}\right)\end{array}$ & - & 39 \\
\hline \multirow{2}{*}{$\begin{array}{l}\text { Mix proportion } \\
\text { by weight }\end{array}$} & & \\
\hline & $1: 1.5: 3$ & $1: 1: 0.25$ \\
\hline \multicolumn{3}{|c|}{$\begin{array}{l}* \text { Percent of cement weight }(25 \%) \\
* * \text { Percent of binder (cement and silica fume) } \\
\text { weight }(6 \%) \text {. } \\
* * * \text { Percent of mix volume }(0.5 \%) \\
* * * * \text { cement: sand: graval for NSC }\end{array}$} \\
\hline
\end{tabular}

cement: sand: silica fume for RPC

Table 2: Mechanical Properties of NC and RPC

\begin{tabular}{|l|c|c|c|}
\hline \multirow{2}{*}{ Type of Test } & $\begin{array}{c}\text { Standard of } \\
\text { test }\end{array}$ & \multicolumn{2}{|c|}{$\begin{array}{c}\text { Type of } \\
\text { Concrete }\end{array}$} \\
\cline { 2 - 4 } & NC & RPC \\
\hline $\begin{array}{l}\text { Average } \\
\text { Cylinder } \\
\text { Compressive } \\
\text { Strength (MPa) }\end{array}$ & $\begin{array}{c}\text { ASTM C } \\
\text { 19/C39M- } \\
15[21]\end{array}$ & 34.4 & 115.5 \\
\hline $\begin{array}{l}\text { Average } \\
\text { modulus of }\end{array}$ & ASTM & & \\
Elasticity (Gpa) & $\begin{array}{c}\text { C469-14 } \\
{[22]}\end{array}$ & 32.5 & 49.75 \\
\hline $\begin{array}{l}\text { Average } \\
\text { Modulus of } \\
\text { Rupture (MPa) }\end{array}$ & $\begin{array}{c}\text { ASTM C 78- } \\
15 \text { [23] }\end{array}$ & 3.95 & 13.5 \\
\hline $\begin{array}{l}\text { Average } \\
\text { Splitting Tensile }\end{array}$ & $\begin{array}{c}\text { ASTMC496- } \\
\text { Strength (MPa) }\end{array}$ & 3.46 & 12.13 \\
\hline
\end{tabular}

\subsection{Specimen Preparation}

The experimental program consists of making and testing twelve simply supported rectangular section beams with large web opening. The each beam is designed steel reinforcement as per ACI318M-14[22] building code and for opening size as the large and location used NZS31012(2006) [23] and Barney et al. [24]. The nominal dimensions of the tested beams are (1250) $\mathrm{mm}$ in overall length, (120) $\mathrm{mm}$ width and (190) $\mathrm{mm}$ in depth, the nominal dimensions of opening were kept constant for all beam with (180) mm length and (60) $\mathrm{mm}$ width. The beams tested under two point's loads with a shear span (av) equal to $410 \mathrm{~mm}$, where av is distance from center of concentrated load $(\mathrm{P} / 2)$ to the center of support. The beams are divided into three groups namely Group 1 with one opening, Group 2 with two openings and Group 3 with three openings. The beams details, layers of RPC and openings locations are shown Fig.1 and dimensions and reinforcement details of tested beams as shown Figs [2 and 3].

\subsection{Test set-up and Instrumentation}

The deflections at the mid-span of the beam were measured using the dial gage of $0.01 \mathrm{~mm}$ accuracy. Two types of strain gauge are used were type (TLM).

Determine behavior of structural member against the applied stresses. The use of devices with high accuracy is required to calculate the amount of strain in the steel and concrete were used. Locations of strain gauge were selected to give an impression about what is happening of strain and stress in each, steel reinforcement and concrete as shown Figs [4,5]. The load is increased gradually and in every $2.5 \mathrm{kN}$ step for all the strain reading is taken by the Data logger. All the beams were tested to failure in two -point loading. The loading was applied through a hydraulic jack Fig.[6] 

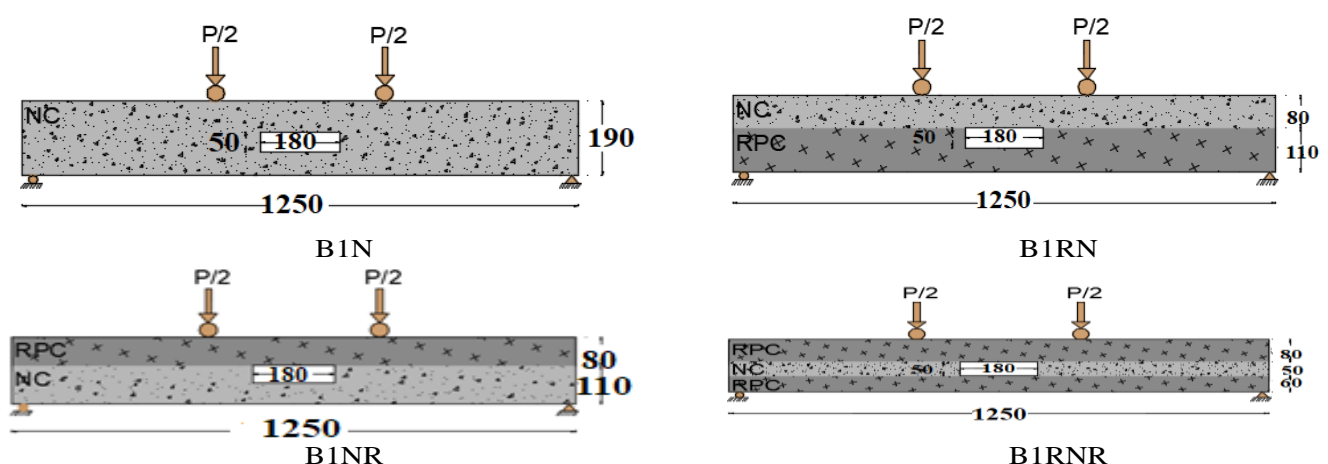

(a) Group one opening at flexural zone location
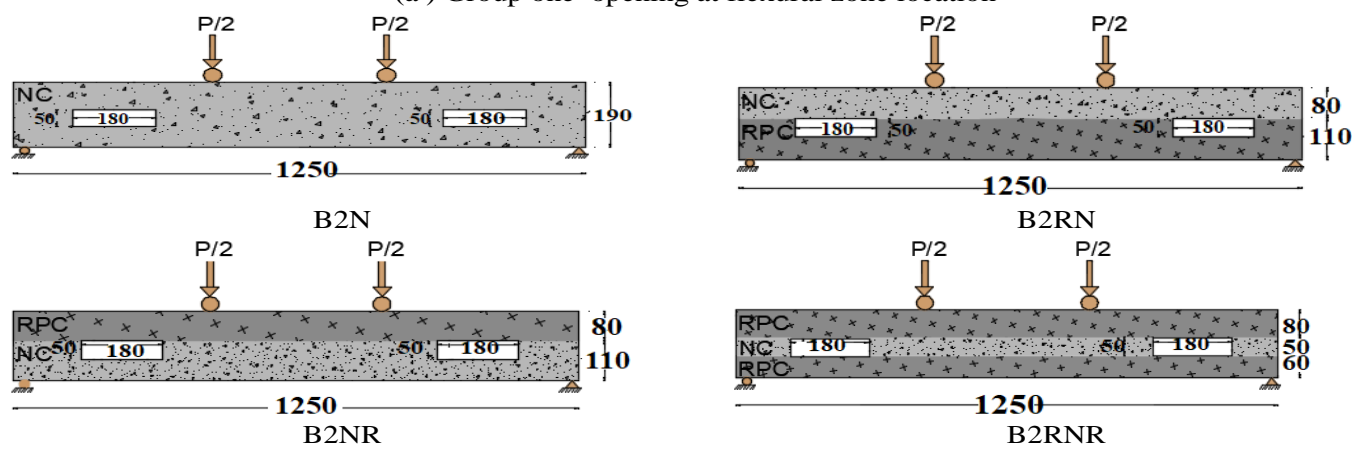

(b) Group two opening at shear zone location
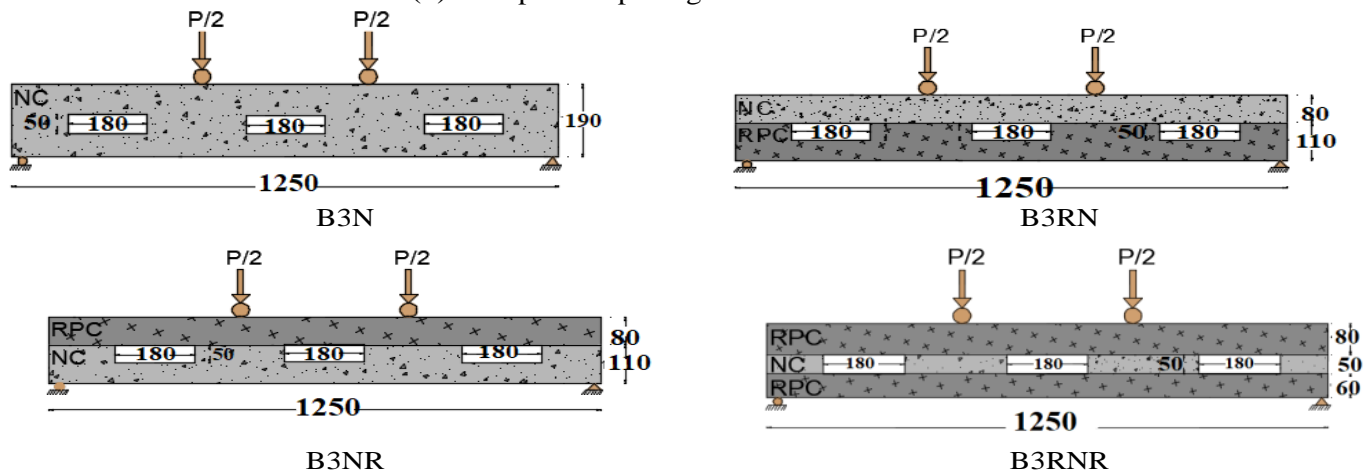

B3NR

B3RNR

(c)Group three opening at compound(Flexural+ Shear)zone location

Figure 1: Beams Details (layers and openings), all Dimensions unit mm
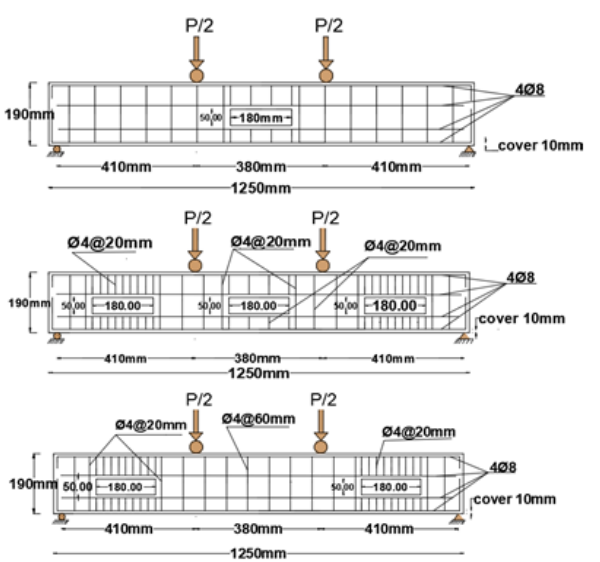

Figure2: Dimensions and Reinforcement Details of Tested Beam

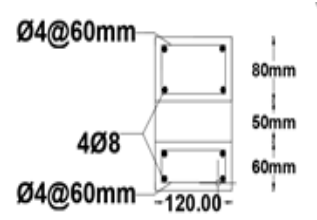
(a) Section of mid span
(b) Section of end
span

Figure 3: Dimensions and Reinforcement Details of the Cross Section 

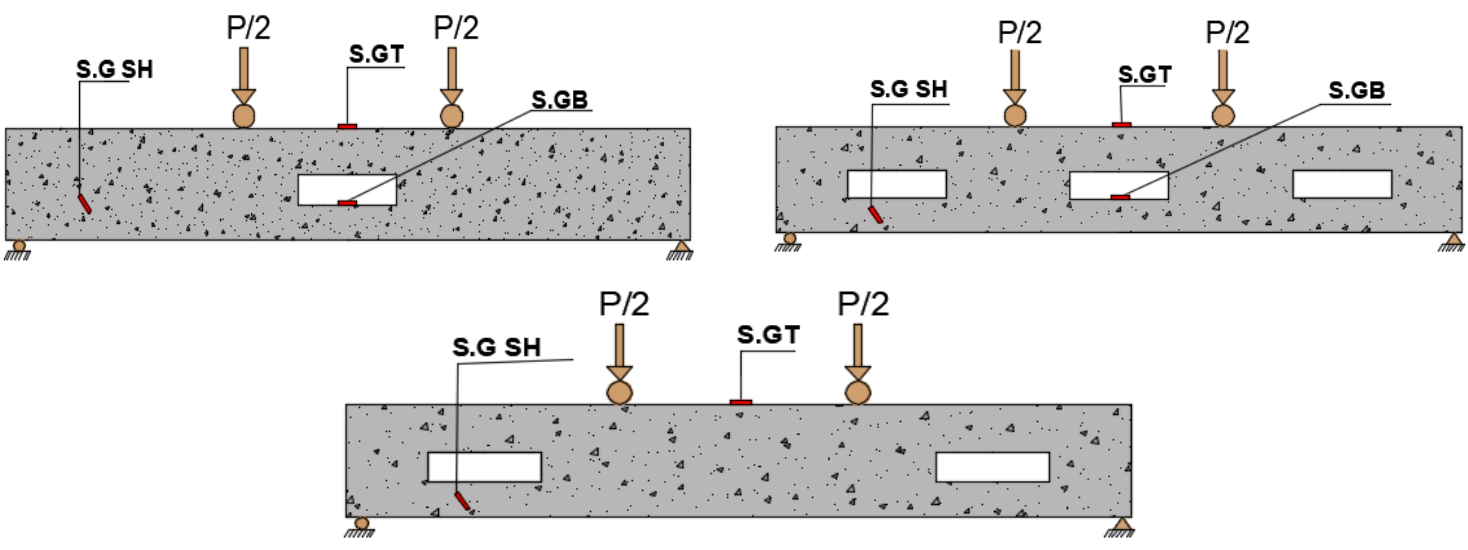

Where: S.GT-strain gage at Top, S.GB-strain gage at Bottom, S.G SH-strain gage at shear zone

Figure 4: Strain Gauge Location of concrete
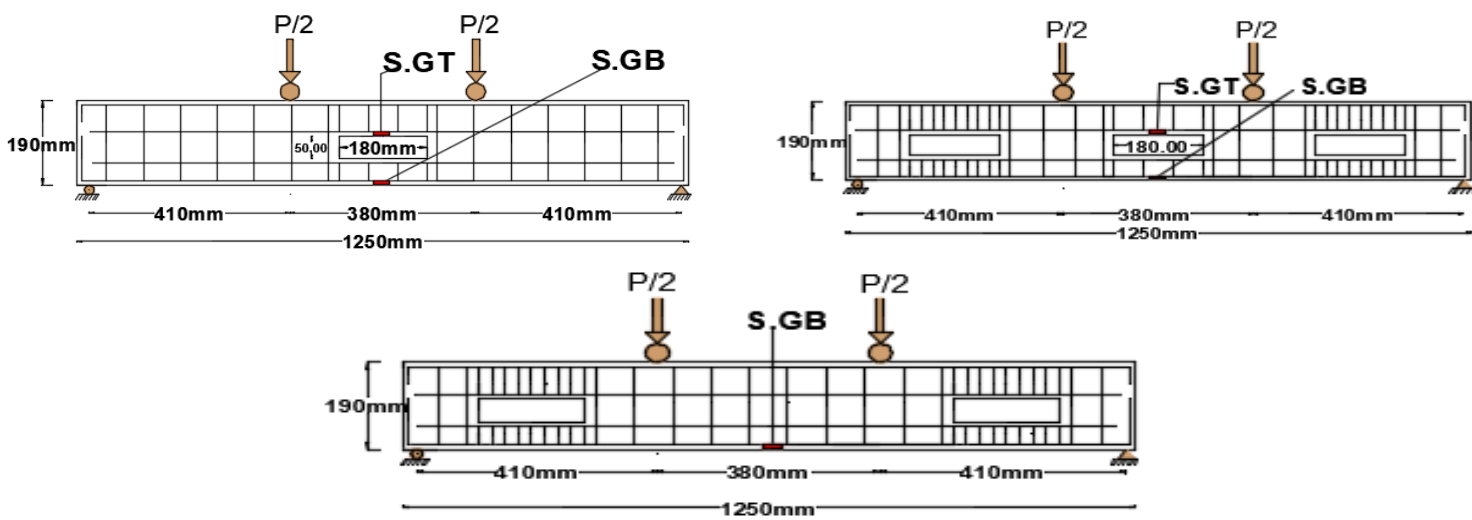

Where: S.GT-strain gage at Top, S.GB -strain gage at Bottom

Figure 5:Strain Gauge Location of Reinforcement

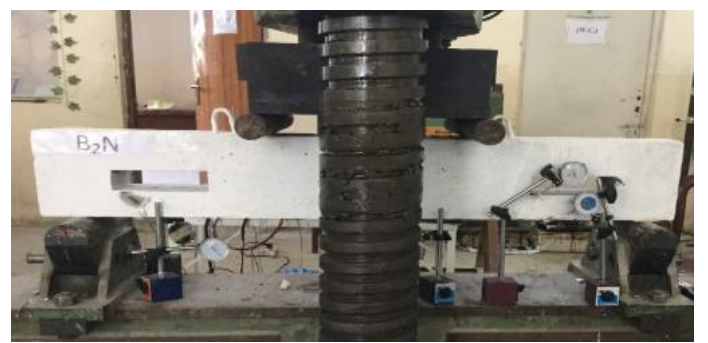

Figure 6:Beam under Test Machine

\section{Results and Discussions}

\subsection{Ultimate Loads}

The reduction in the ultimate failure loads results presented in the Table.3. It is clear that the location and number of openings not only reduced the ultimate load capacity of the beam but also changed the failure mode from a flexural mode to a shear mode of failure. The results presented in the Table.4 generally show that ultimate loads $(\mathrm{Pu})$ increase with the increase of RPC layer hybrid beams with RPC layer in compression gives higher ultimate loads than those of hybrid beams with
RPC layer in tension. All above results indicate that using RPC in compression and tension is more effective than using RPC in compression only and tension only This behavior may be attributed to the combined contribution in increasing the beams stiffness which allows such beams to sustain higher loads before failure.

Table 3: Effect of Number of Opening in Ultimate Loads

\begin{tabular}{|c|c|c|c|}
\hline $\begin{array}{c}\text { Number of } \\
\text { openings }\end{array}$ & Beams & Pu (kN) & $\begin{array}{c}\text { Percentage } \\
\text { of reduction } \\
(\%)\end{array}$ \\
\hline 1 & B1N & 92.50 & 0 \\
\hline 2 & B2N & 85.00 & 8 \\
\hline 3 & B3N & 77.50 & 16 \\
\hline 1 & B1RN & 94.00 & 0 \\
\hline 2 & B2RN & 88.00 & 6 \\
\hline 3 & B3RN & 80.00 & 14 \\
\hline 1 & B1NR & 117.50 & 0 \\
\hline 2 & B2NR & 105.00 & 10 \\
\hline
\end{tabular}


NJES Vol.21, No.3, 2018

\begin{tabular}{|c|c|c|c|}
\hline 3 & B3NR & 92.50 & 21 \\
\hline 1 & B1RNR & 129.00 & 0 \\
\hline 2 & B2RNR & 125.00 & 3 \\
\hline 3 & B3RNR & 101.50 & 21 \\
\hline
\end{tabular}

Table 4: Effect of RPC layers in Ultimate loads

\begin{tabular}{|c|c|c|c|c|}
\hline \multicolumn{2}{|c|}{ Open location } & \multirow{2}{*}{$\begin{array}{c}\text { Beams } \\
\text { B1N }\end{array}$} & \multirow{2}{*}{$\begin{array}{c}\begin{array}{c}\mathbf{P u} \\
(\mathbf{k N})\end{array} \\
92.5 \\
\end{array}$} & \multirow{2}{*}{$\begin{array}{c}\text { Percentage of } \\
\text { increase }(\%)\end{array}$} \\
\hline \multirow{4}{*}{$\begin{array}{l}\text { Flexural } \\
\text { zone }\end{array}$} & \multirow{4}{*}{$\mid$\begin{tabular}{r|}
$\overrightarrow{0}$ \\
0 \\
0 \\
0
\end{tabular}} & & & \\
\hline & & B1RN & 94 & 1 \\
\hline & & B1NR & 117.5 & 27 \\
\hline & & B1RNR & 129 & 39 \\
\hline \multirow{4}{*}{$\begin{array}{l}\text { Shear } \\
\text { zone }\end{array}$} & \multirow{4}{*}{ 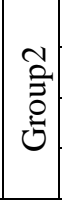 } & $\mathrm{B} 2 \mathrm{~N}$ & 85 & 0 \\
\hline & & B2RN & 88 & 3 \\
\hline & & B2NR & 105 & 23 \\
\hline & & B2RNR & 125 & 47 \\
\hline \multirow{4}{*}{$\begin{array}{c}\text { Compoud } \\
\text { (Flexural+ } \\
\text { Shear) } \\
\text { zone }\end{array}$} & \multirow{4}{*}{ 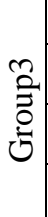 } & B3N & 77.5 & 0 \\
\hline & & B3RN & 80 & 3 \\
\hline & & B3NR & 92.5 & 19 \\
\hline & & B3RNR & 101.5 & 30 \\
\hline
\end{tabular}

\subsection{Failures Modes}

The type of failure of tested beams with opening was characterized by the formation of cracks at the location as shown Figs [7 through 9]. Failure modes of tested beam are given Table.5.

Table 5: Modes of failures of the tested beams

\begin{tabular}{|c|c|}
\hline Beams & Failure modes of RC with openings \\
\hline B1N & Flexure \\
\hline B2N & Shear \\
\hline B3N & Beam-Type Shear Failure \\
\hline B1RN & Flexure and Crush At Flexural \\
\hline B2RN & Shear \\
\hline B3RN & $\begin{array}{c}\text { Vierendeel Truss Action, Beam-Type } \\
\text { Shear Failure and Crush At Shear }\end{array}$ \\
\hline B1NR & Flexure and Crush At Flexural \\
\hline B2NR & Shear \\
\hline B3NR & $\begin{array}{c}\text { Tension-Controlled Flexural Failure and } \\
\text { Beam-Type Shear Failure }\end{array}$ \\
\hline B1RNR & Flexure and Crush At Flexural \\
\hline B2RNR & Shear \\
\hline B3RNR & $\begin{array}{r}\text { Vierendeel Truss Action and Beam- } \\
\text { Type Shear Failure }\end{array}$ \\
\hline
\end{tabular}

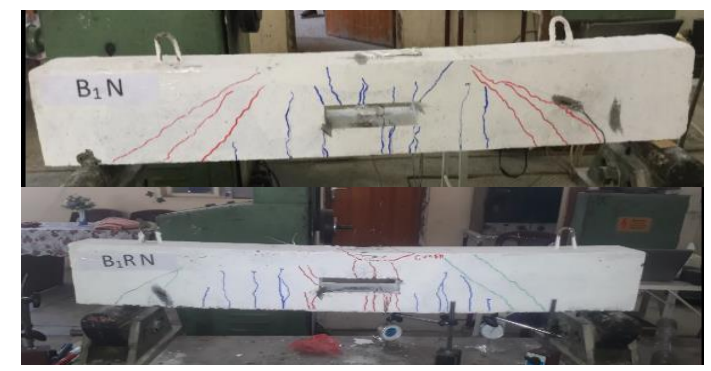

Jassim \& Jarallah, pp.405-416

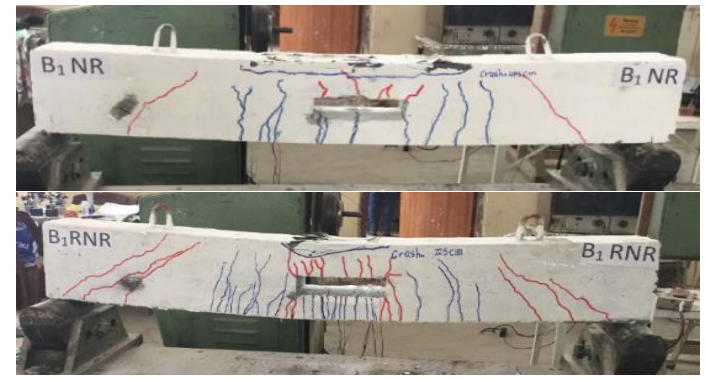

Figure 7: Crack patterns at failure stage for(Group one)

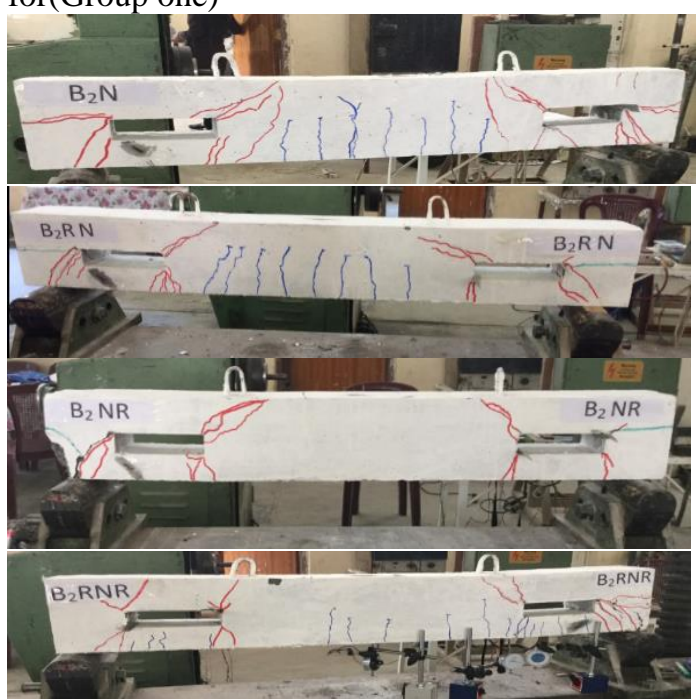

Figure 8: Crack patterns at failure stage for (Group two)

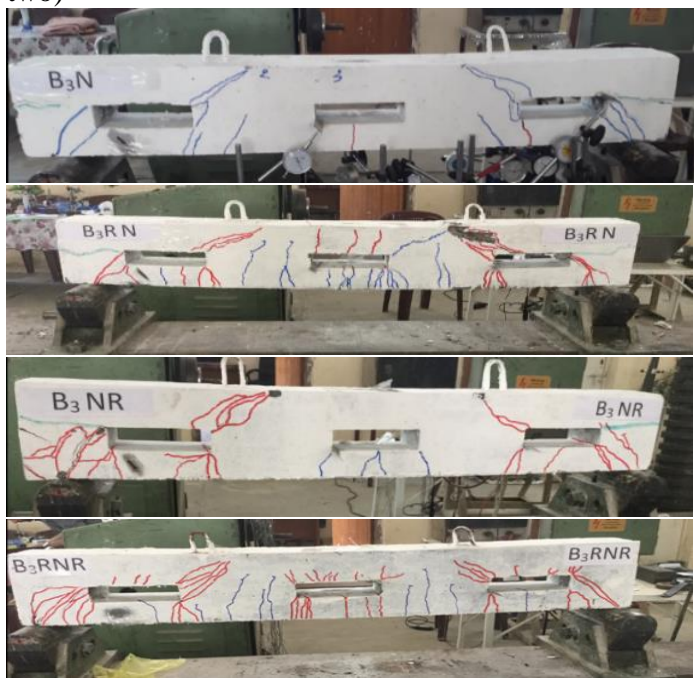

Figure 9: Crack Patterns at failure stage for (Group three)

\subsection{Load-Deflection Curves}

Figures 10 through 16 shows load-mid-span deflection relationships for dial gage at mid-span and for all tested beams. The load deflection curves are discussed of as below.

\subsubsection{Effect of openings}

The maximum mid-span deflection is increased with increased number of opening as shown in Table. 6. It can be noticed when increase in the number of openings in the beams causes reduction 
NJES Vol.21, No.3, 2018

both ultimate load and their stiffness so causes increase in their deflections as shown Figs [10 through 13].

Table 6: Effect of Number of Opening in maximum mid-span deflection

\begin{tabular}{|c|c|c|c|}
\hline $\begin{array}{c}\text { Number } \\
\text { of } \\
\text { openings }\end{array}$ & Beams & $\begin{array}{c}\text { Load } \\
(\mathbf{k N})\end{array}$ & $\begin{array}{c}\text { maximum } \\
\text { mid-span } \\
\text { deflection } \\
(\mathbf{m m})\end{array}$ \\
\hline 1 & B1N & 87.5 & 9 \\
\hline 2 & B2N & 82.5 & 11 \\
\hline 3 & B3N & 77.5 & 13 \\
\hline 1 & B1RN & 87.5 & 5.4 \\
\hline 2 & B2RN & 87.5 & 7 \\
\hline 3 & B3RN & 77.5 & 9 \\
\hline 1 & B1NR & 112.5 & 7.2 \\
\hline 2 & B2NR & 100 & 9 \\
\hline 3 & B3NR & 90 & 12 \\
\hline 1 & B1RNR & 125 & 11 \\
\hline 2 & B2RNR & 122.5 & 13 \\
\hline 3 & B3RNR & 97.5 & 15.55 \\
\hline
\end{tabular}

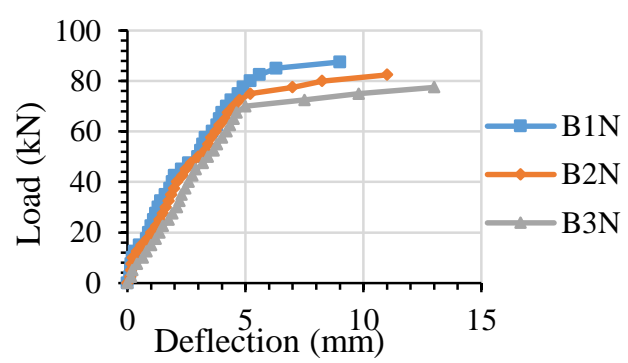

Figure 10: Effect number of openings on loaddeflection for beams with $\mathrm{NC}$

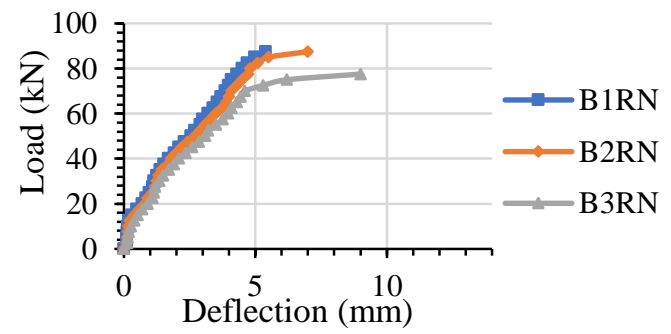

Figure 11: Effect number of openings on loaddeflection for beams with RPC and NC layers

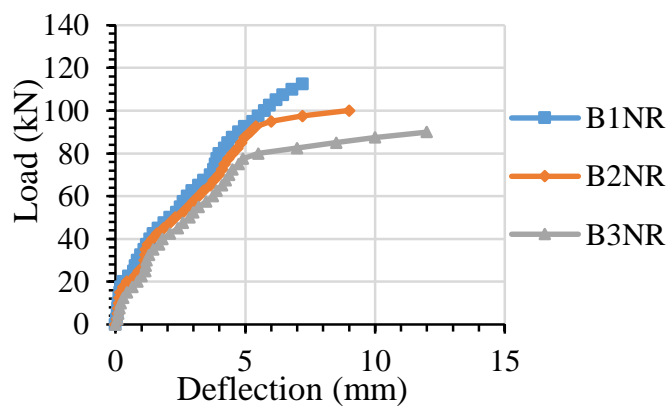

Figure 12: Effect number of openings on loaddeflection for beams with NC and RPC layers
Jassim \& Jarallah, pp.405-416

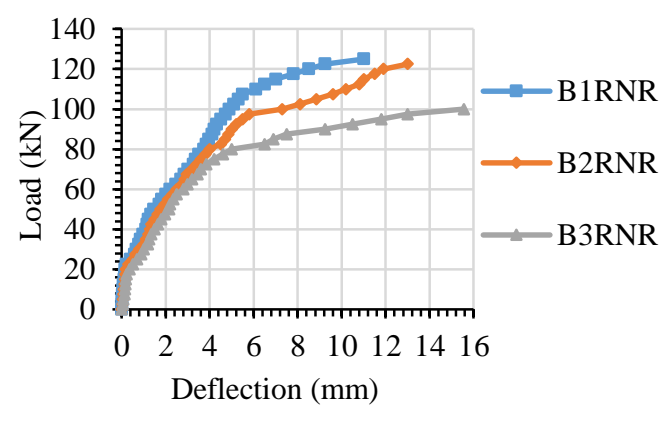

Figure 13: Effect number of openings on loaddeflection for beams with RPC ,NC and RPC layers

\subsubsection{Effect of RPC layers}

From Table.7 noted that the maximum midspan deflections of hybrid beams with different RPC layers hybrid beams with one layer of RPC in compression show a stiffer behavior than that of hybrid beams with one layer of RPC in tension. Maximum mid-span deflections of hybrid beams with one layer of RPC in tension zone were lower than that of NC beams for all beams, while hybrid beams with RPC in tension and compression show higher maximum deflections than NC because of their high ductility. This may be attributed to the higher flexural strength of these beams which allows them to withstand larger deflections before failure (higher energy absorption) as shown Figs. 14,15 and 16.

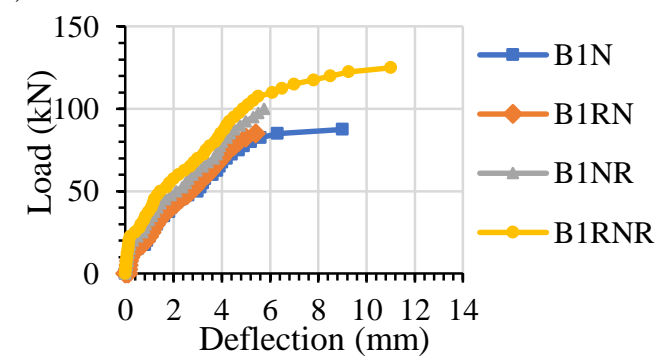

Figure 14: Load-Deflection Curve for group one opening at Flexural zone

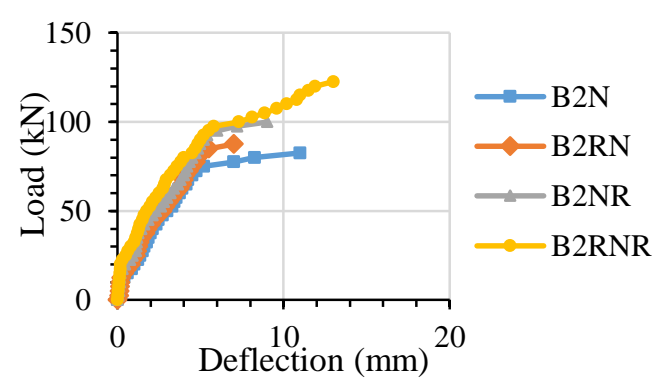

Figure 15: Load-Deflection Curve for group two openings at Shear zone 
NJES Vol.21, No.3, 2018

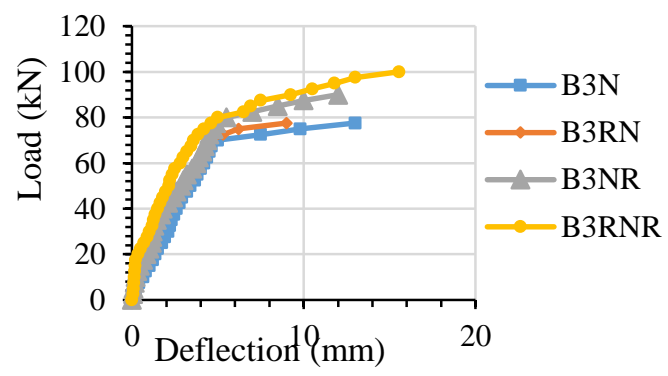

Figure 16: Load-Deflection Curve for group three openings at compound (Flexural+ Shear) zone

Table7: Effect of RPC layers in maximum midspan deflections

\begin{tabular}{|c|c|c|c|c|}
\hline $\begin{array}{c}\text { Open } \\
\text { location }\end{array}$ & & Beams & $\begin{array}{l}\text { Load } \\
\text { (kN) }\end{array}$ & $\begin{array}{c}\text { maximum } \\
\text { mid-span } \\
\text { deflection } \\
(\mathrm{mm})\end{array}$ \\
\hline \multirow{4}{*}{$\begin{array}{l}\text { Flexural } \\
\text { zone }\end{array}$} & \multirow{4}{*}{$\begin{array}{l}\overline{0} \\
\text { ò } \\
\text { J }\end{array}$} & B1N & 87.5 & 9 \\
\hline & & B1RN & 87.5 & 5.4 \\
\hline & & B1NR & 112.5 & 7.2 \\
\hline & & B1RNR & 125.5 & 11 \\
\hline \multirow{4}{*}{$\begin{array}{l}\text { Shear } \\
\text { zone }\end{array}$} & \multirow{4}{*}{ 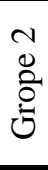 } & B2N & 82.5 & 11 \\
\hline & & B2RN & 87.5 & 7 \\
\hline & & B2NR & 100 & 9 \\
\hline & & B2RNR & 122.5 & 13 \\
\hline \multirow{4}{*}{$\begin{array}{l}\text { compound } \\
\text { (Flexural } \\
\text { and Shear) } \\
\text { zone }\end{array}$} & \multirow{4}{*}{ 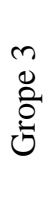 } & B3N & 77.5 & 13 \\
\hline & & B3RN & 77.5 & 9 \\
\hline & & B3NR & 90 & 12 \\
\hline & & B3RNR & 97.5 & 12.5 \\
\hline
\end{tabular}

\subsection{Load - Strain Relationships}

Strain were measured at the concrete and steel for all tested beams. In general, as load increases; strain distributions are changed from approximately linear at lower loads to nonlinear at higher loads. The strain values discussed as below.

3.4.1Concrete strain at top and bottom chords of openings

\subsubsection{1 beam with opening at flexure zone}

The value of the concrete strain recorded at top chord is greater than the bottom chord due to compression stresses higher the top chord of the bottom chord and this is intended to increase the strain. The maximum measured compressive strain on concrete surface for beam B1RNR at top edge was (0.00418), the strain exceeds the ultimate strain of concrete as a result, and crushing in compression concrete was observed. The strain in the compression face at top chord approaching the ultimate strain of concrete for beams B1RN and B1NR as shown Fig .17.
Jassim \& Jarallah, pp.405-416

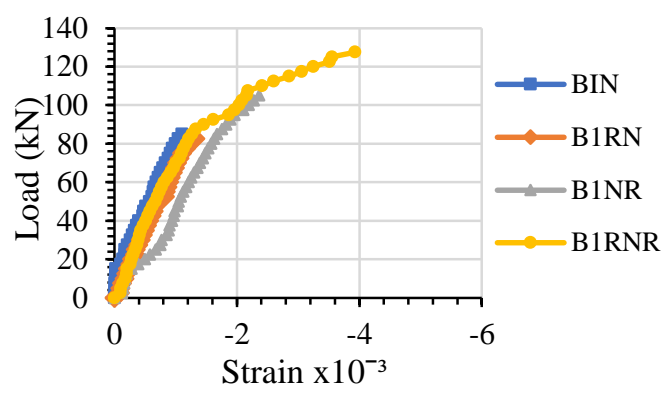

(a) Top edge

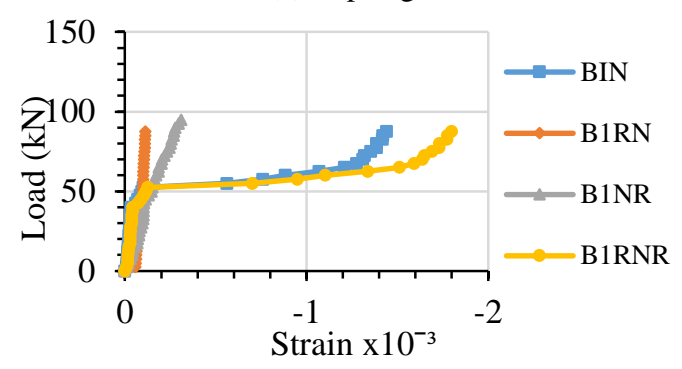

(b) Bottom edge

Figure17: Load-concrete strain relationships for group one opening at Flexural zone

\subsubsection{2 beam with opening at shear zone}

The maximum measured compressive concrete strain on concrete surface for beam B2RNR was (0.00217), the value of the strain recorded is less than group one because there is no opening in mid span, that opening is divided the beam to the top and bottom chord and ultimate load less compare with one opening. The strain in the compression face for all beams are not approaching the ultimate strain of concrete as shown Fig.18.

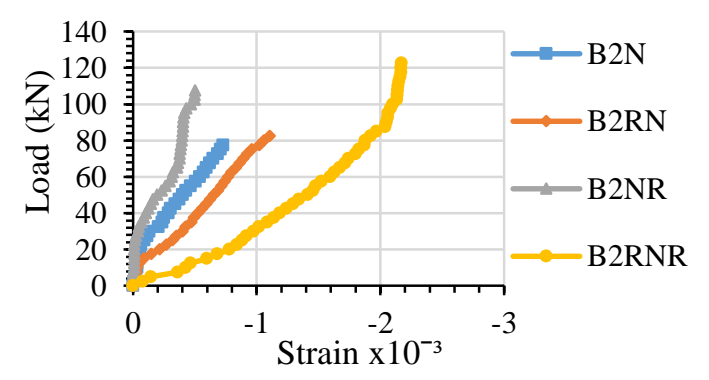

Figure 18: Load - concrete strain relationships for group two openings at Shear zone

3.4.1.3 Beam with two openings located at shear zone and one opening located at flexural zone

The maximum compressive concrete strain was $(0.002)$ for beams B3RN,B3RNR and B3RNR, the maximum compressive concrete strain for beams with three openings are less than for strain of beams with one opening and two openings as shown Fig.19 (a),(b). It can be concluded that the use of RPC layer at tension face of hybrid beams leads to increase the ultimate concrete strain at both tension and compression zones with more evidence in tensile strain due to having higher load 
NJES Vol.21, No.3, 2018

capacity and reflecting the effectiveness of steel zones to improve ductility and tensile behavior.

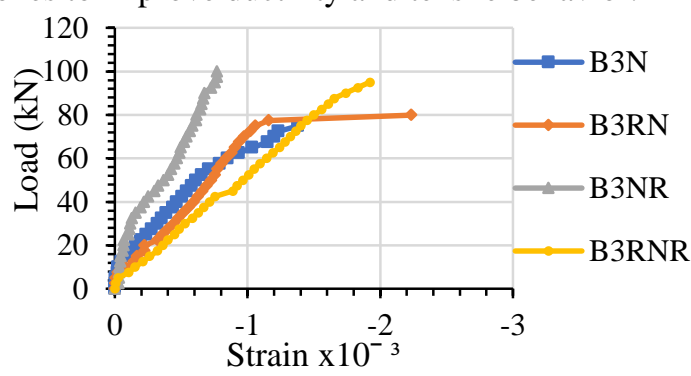

(a) Top edge

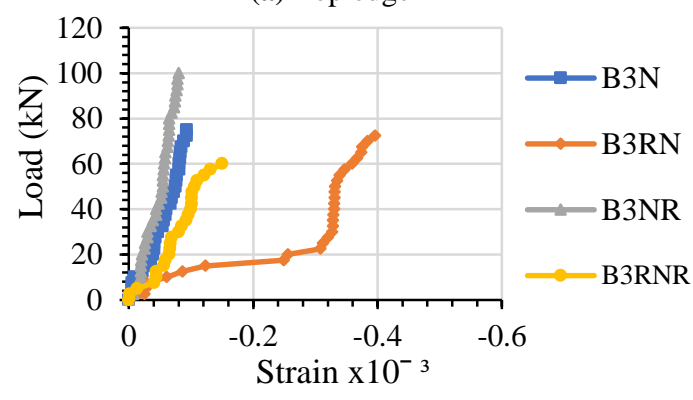

(b) Bottom edge

Figure 19: Load-concrete strain relationships for group three openings at compound (Flexural and Shear) zone.

\subsubsection{Strain of Steel reinforcement}

\subsubsection{Beam with opening at flexure zone}

The load-steel tensile strain curve obtained for beams under static load as shown in Fig.20, it can be noted that the yield strain $\left(\varepsilon_{y}=0.002361\right)$ and maximum strain $\left(\varepsilon_{u}=0.003433 .6\right)$ is occurred at the bottom chord for all beams. It may also be noted that the strain values all beams at bottom chord was exceeded the ultimate strain. However, at the top chord, the steel strains is below the yield strain and the ultimate strain for all beams. The maximum strain is occurred at beam B1RNR because of this beam has higher ultimate load than other beams that it is gain from RPC layers at top and bottom. The RPC layers at top or bottom face beam increasing strains because of the RPC had higher ultimate load rather than normal concrete.

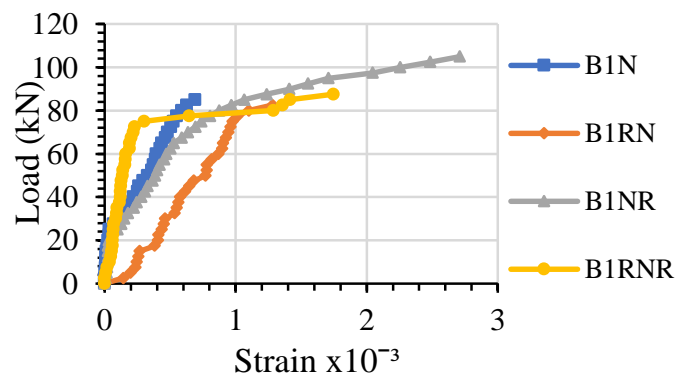

(a): top edges
Jassim \& Jarallah, pp.405-416

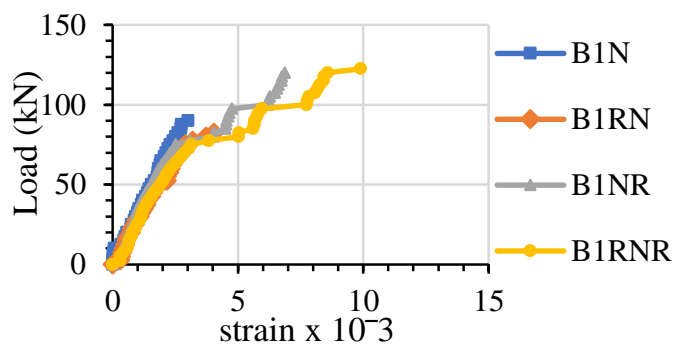

(b) bottom edges

Figure 20: Load - steel strain relationships for group one opening at flexural zone

\subsubsection{Beams with opening at shear zone}

From the load-steel tensile strain curve obtained for beams under static load as shown in Fig.21, it can be noted that the maximum strain is occurred at the bottom longitudinal reinforcement for beam B2RNR because of this beam has higher ultimate load than other beams. It may also be noted that the strain values for bottom exceed the yield strain for all beams and approach from the ultimate strain. However, the load level occurred at all beams is below the load level for group one opening because of the openings reduces the ultimate load

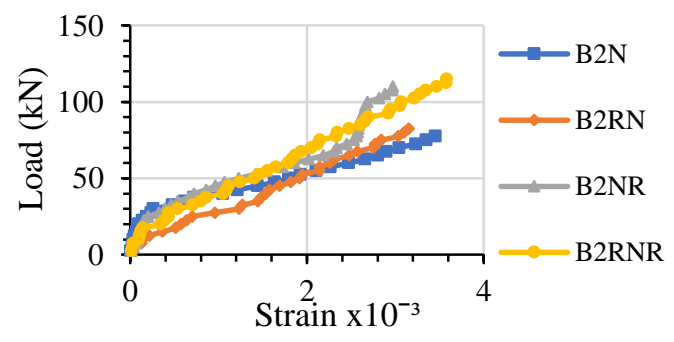

Figure 21: Load - steel strain relationships for group two openings at shear zone.

3.4.2.3 Beams with two openings Located at shear zone and one opening located at flexural zone

From the load-steel tensile strain curve obtained for beams shown in Fig. 22, it can be noted that the maximum strain is occurred at the bottom chord for all beams and the first yield occurred at bottom chord for all beams. It may also be noted that the strain values for bottom chord was exceeded the ultimate strain for all beams. However, the strains occurred at the top chord is below the yield strain for all beams. The maximum strain is occurred at beam B3RNR because this beam has higher ultimate load than other beams that it is gain from RPC layers at top and bottom face. The RPC layer in top or bottom face were increased the strains because RPC has higher ultimate load than NC. However, the load level occurred at all beams is below the load level for group one opening and group two openings because of the openings reduces the ultimate load. 
NJES Vol.21, No.3, 2018

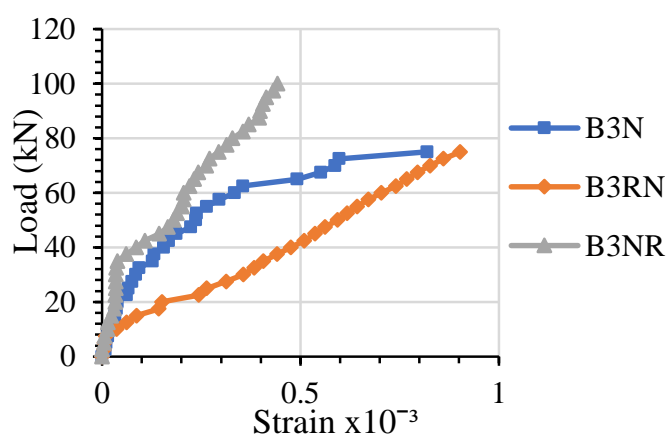

(a) top edges

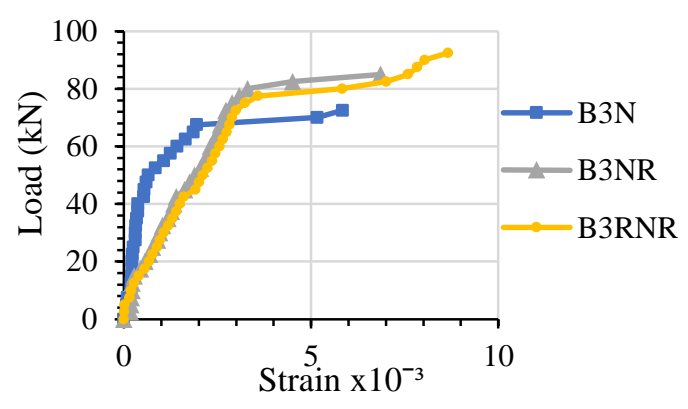

(b) bottom edges

Figure 22:Load - steel strain relationships for group three openings at compound (Flexural and Shear) zone

\subsection{Neutral Axis Depth}

The experimental neutral axis depth in compression zone, c, of the test beams is obtained from the experimentally measured strain values for concrete at compression face and the reinforcement at tension face. When cracks occurred, the neutral axis shifted upward and the c/d value drops considered that the stress equivalent to first crack strength is developed in RPC after generating crack, because the crack width of RPC is as small as $0.1 \mathrm{~mm}$ or less. The variation of neutral axis depth ratio (c/d) are discussed as below.

\subsection{1 beam with opening at flexure zone}

It can be noted from Fig.23 that the ratio of (c/d) for top edge is more than for bottom edge at all load levels. These results are attributed the top edge at compression face and when the loading start, it is under the influence of compression the value of c approach to $d$ but as the load increases, the value starts to decrease and the part of tension and compression appears at top edge. The ratio of (c/d) for bottom edge when the loading start was (0.45) with increase loading the (c/d) reduces. When cracks occurred, the neutral axis shifted upward and the c/d value drops.
Jassim \& Jarallah, pp.405-416

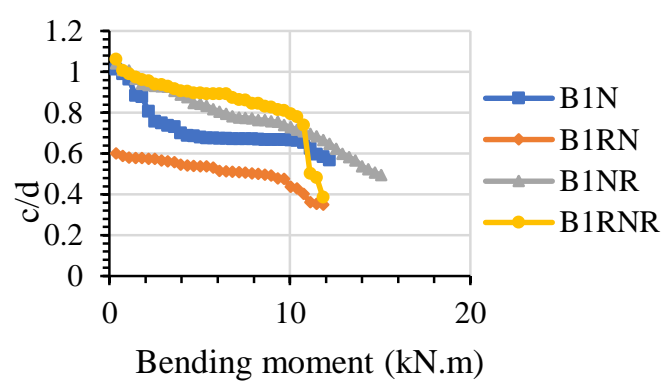

(a) top edge

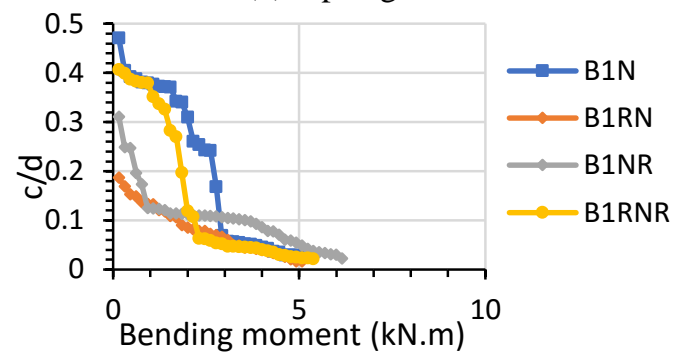

(b) bottom edges.

Figure 23:Behavior of neutral axis depth for group one opening at flexural zone

\subsection{2 beam with opening at shear zone}

It can be noted from Fig.24 that the ratio of (c/d) is less than that at group one opening because of there is no opening in the flexure zone works to cut the beam to top and bottom edges in this case the section is solid

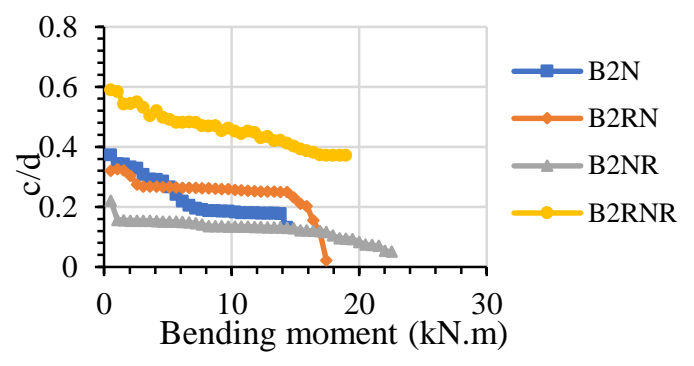

Figure 24: Behavior of neutral axis depth for group two openings at shear zone.

\subsubsection{Beam with two openings located at shear zone and one opening located at flexural zone}

It can be noted from Fig.25 that the ratio of (c/d) for top edge is more than for bottom edge at all load level as observed for beam with opening at flexure zone. The strain could not be measured for beam B3RNR at top edge because of damage and failure of the strain gauges during the testing. ratio of (c/d) for bottom edge at the beginning of the loading was (0.4). the increase loading level that leads to reduce the $(\mathrm{c} / \mathrm{d})$. The strain could not be measured beam B3RN at bottom edge because of damage and failure of the strain gauges during the testing. When cracks occurred, the neutral axis shifted upward and the c/d value drops. In all groups some fluctuations of the $\mathrm{c} / \mathrm{d}$ values took place at low level of loading due to the sensitivity of the strain gage readings specially before 
NJES Vol.21, No.3, 2018

cracking. The hybrid beams with RPC layer at tension face, the fibers bridge the cracks and reduce crack width which in turn reduce the strain in the tension face and therefore reduces the ratio $(\mathrm{c} / \mathrm{d})$.

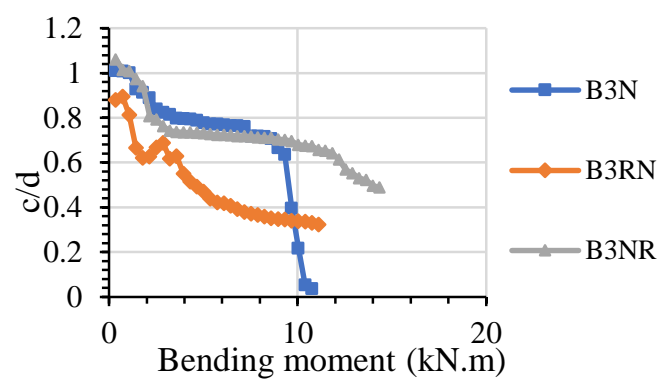

(a) top edge.

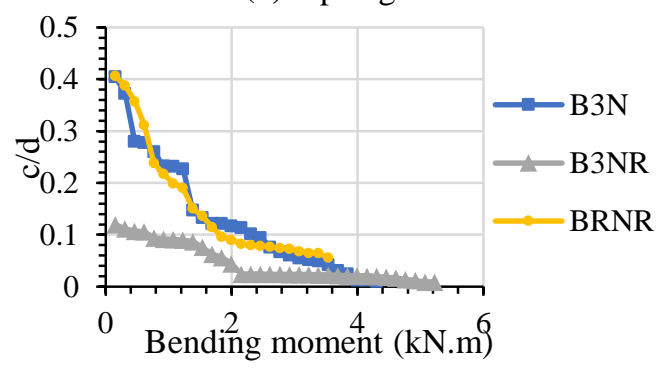

(b) bottom edges

Figure25:Behavior of neutral axis depth for group three openings at compound (flexural+ shear) zone

\subsection{Curvature}

The bandings moment values are need to calculate the curvature for top and bottom chord therefore the bending moments were assumed $0.7 \mathrm{Mt}$ and $0.3 \mathrm{Mt}$ for top and bottom chord respectively, where $\mathrm{Mt}$ is applied moment at the section. The opening locations and RPC layers are effect the calculation of curvature. The RPC has little effect on the increase in curvature with the increase of bending moment after the generation of cracking. Figures 26 through 28 shows the variation of the curvature with the applied bending moment.

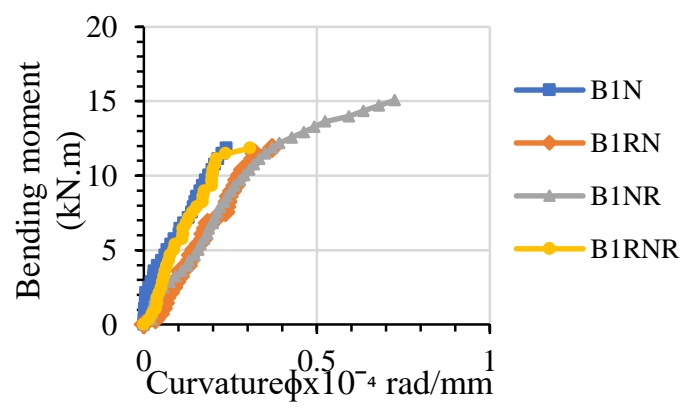

(a) top edge

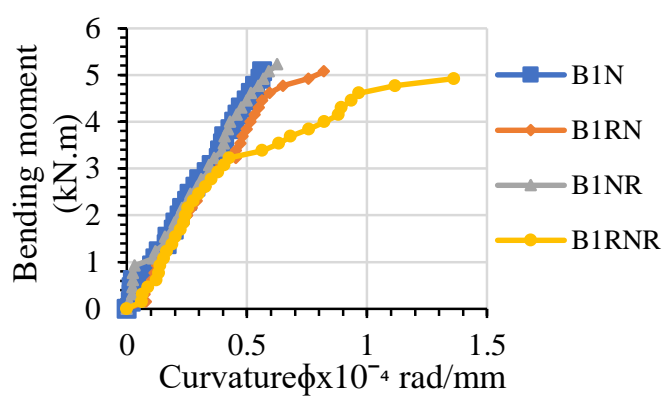

(b) bottom edges

Figure 26:Moment-curvature relationship for group one opening at flexural zone

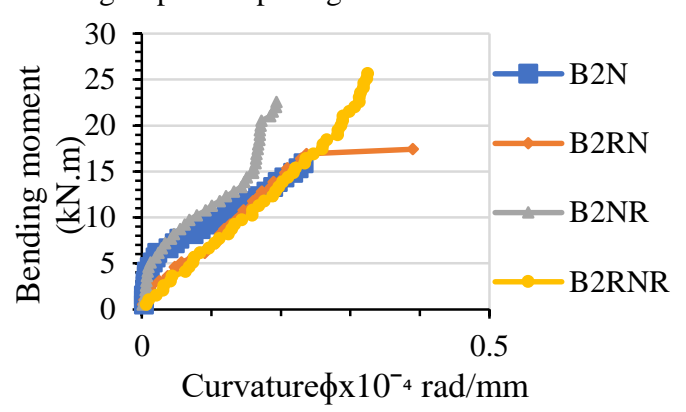

Figure 27: Moment-curvature relationship for group two openings at shear zone.

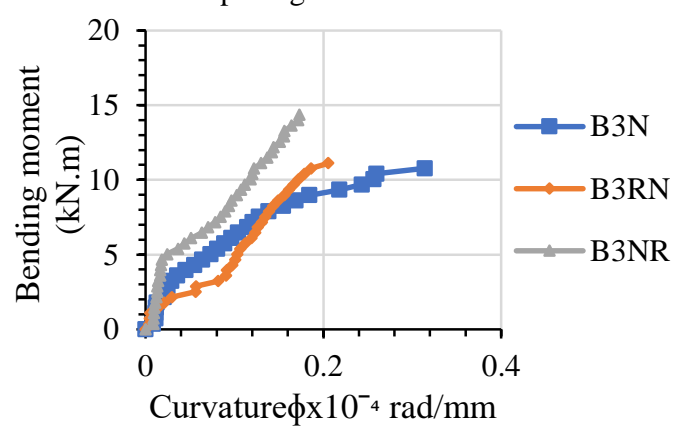

(a) top edge

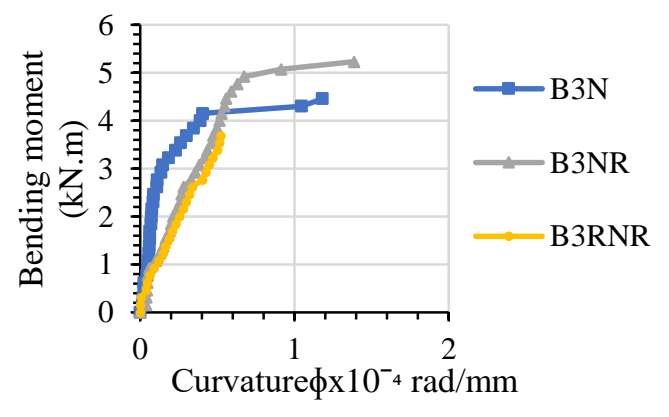

(b) bottom edges

Figure28:moment-curvature relationship for group three openings at compound (flexural+ shear)

zone

\section{Conclusion}

Based on the results obtained in the present research paper the following conclusions can be drawn:

1- The stiffness and ultimate strength were decreased when number of opening are increase. 
2- Using RPC in a reinforced concrete beam with opening its significantly increase its stiffness and ultimate strength.

3- The failure mode depended on openings location, there for the flexure failure, shear failure and combined failure are recorded at the tested beams with one opening, two opening and three opening, respectively.

4- The deflection of normal concrete have two and three openings increase at the ultimate loads about (22 and 44) \% compare with that one opening respectively.

5- The reduction in the ultimate failure loads of the normal beams with two and three openings were (8.1 and 16.21) \% respectively lesser than those of reference beam with one opening.

6- Using RPC in two layers in tension and compression are more effective than using RPC in one layer tension or compression only.

7- It can be noticed when increase the number of openings in the beams causes reduction in ultimate load and their stiffness so causes increase in their deflections.

8- It can be noted that the maximum concrete strain is occurred at the bottom edge for all beams. The strain increase with increased number of openings. 9- The strain increase with increased number of openings because the exiting of opening in shear zone and therefore there is weakness in this zone. It can be noted that the maximum strain is occurred at the bottom edge for all beams.

10- When increasing load, neutral axis location moves up towards the compressed face of the cross section.

11- The curvature of the beam with opening and fortified with RPC can be evaluated by using same procedure used in curvature calculation reinforced concrete beam.

\section{References:}

[1]Mansur, M. A., and Tan, K., "Concrete beams with openings: Analysis and design", CRC Press, vol.20, 1999.

[2] Allam, S. M., "Strengthening of RC Beams with Large Openings in the Shear Zone", Alexandria Engineering Journal, vol.44 (1), pp 59-78, 2005.

[3] Amiri, S., Reza, M., and Ali Akbar, P., "The study of the Effects of Web Openings on the Concrete Beams", Australian Journal of Basic and Applied Sciences, vol.5 (7), pp547-556, 2011.

[4] Wille, K., Naaman, A. E., and ParraMontesinos, G. J., "Ultra-High Performance Concrete with Compressive Strength Exceeding $150 \mathrm{MPa}(22 \mathrm{ksi})$ : A Simpler Way", ACI Materials Journal, vol. 108(1). 2011.

[5] Wille, K., Naaman, A.E. and El-Tawil, S., "Optimizing Ultra-High Performance Fiberreinforcedconcrete", Concrete international, vol. 33(9), pp.35-41. 2011
Jassim \& Jarallah, pp.405-416

[6] Mansur, M. A., "Design of Reinforced Concrete Beams with Web Openings", In Proceedings of the 6th Asia-Pacific Structural Engineering and Construction Conference (ASPEC 2006), pp. 5-6. 2006.

[7] Aykac, B., Kalkan, I., Aykac, S. and Egriboz, Y.E., "Flexural Behavior of RC Beams With Regular Square or Circular Web Openings", Engineering Structures, Vol. 56, pp.2165-2174. 2013

[8] Egriboz, Y. E., "Behaviour and Strength of $R / C$ Beams with Regular Rectangular or Circular Web Openings", MSc thesis, Gazi University, Ankara, Turkey, pp. 27-35. 2008.

[9] Tanijaya, J. and Hardjito, D., "The Influence Of Opening On The Responses Of Hybrid Reinforced Concrete T-Beams Under Cyclic Loading", In: Proceeding of the 5th Civil engineering conference in the Asian region and Australasian, Structural engineering conference, 2010.

[10] Abdalla, H.A., Torkey, A.M., Haggag, H.A. and Abu-Amira, A.F., "Design against cracking at openings in Reinforced Concrete Beams Strengthened with Composite Sheets", Composite Structures, vol. 60(2), pp.197-204. 2003.

[11] Pimanmas, A., "Strengthening $R / C$ beams with Opening by Externally Installed FRP Rods: Behavior and Analysis", Composite Structures, vol. 92(8), pp.1957-1976. 2010.

[12] Ismael, M. A.," Flexural Behavior of Reactive Powder Concrete Tee Beams", Ph.D. Civil Engineering Department College of Engineering, Al-Mustansiriya University, Baghdad, Iraq, (2013), pp.1-217.

[13] Raj, J. and Jeenu, G., "Flexural Behavior of UHPC-RC Composite Beams", Proceedings of International Conference on Technological Trends (ICTT-2010) College of Engineering/ Trivandrum, India, 5pp, 2010.

[14] Mohammed, M. H., "Flexural Behavior of Hybrid Beams Containing Reactive Powder Concrete and Conventional Concrete" ,Ph.D. Civil Engineering Department College of Engineering, Al-Mustansiriya University, Baghdad, Iraq,pp.1192, 2013.

[15] ASTM A615, "Standard Specification for Deformed and Plain Carbon Structural Steel Bars for Concrete Reinforcement", Annual Book of ASTM Standards, 2016.

[16] ASTM A496-02, "Standard Specification For Steel Wire Deformed, For Concrete Reinforcement". Annual Book of ASTM Standards, 2002.

[17] ASTM C191 - 13,"Standard Test Methods for Time of Setting of Hydraulic Cement by Vicat Needle”, Philadelphia, PA: American Society for Testing and Materials, West Conshohocken, USA, 2013. 
NJES Vol.21, No.3, 2018

[18] ASTM C39/C39M, "Standard Test Method for Compressive Strength of Cylindrical Concrete Specimens", Philadelphia, PA: American Society for Testing and Materials, West Conshohocken, USA. , 2015

[19] ASTM C469/C469M, "Standard Test Method for Static Modulus of Elasticity and Poisson's Ratio of Concrete in Compression", Philadelphia, PA: American Society for Testing and Materials, West Conshohocken, USA. 2014.

[20] ASTM C78, "Standard test method for flexural strength of concrete (using simple beam with third-point loading". Philadelphia, PA: American Society for Testing and Materials, West Conshohocken, USA. 2015

[21] ASTM C496. "Standard Specification For Splitting Tensile Strength Of Cylindrical Concrete
Jassim \& Jarallah, pp.405-416

Specimens", Philadelphia, PA: American Society for Testing and Materials, West Conshohocken, USA. 2011

[22] ACI Committee 318, "Building Code Requirement for Structural Concrete and Commentary", American Concrete Institute, pp.520, 2014.

[23] New Zealand Standard NZS3101-2 part 2 Concrete Structural Standard, C9.3.11, pp.157, 2006.

[24] Barney,G.B., Corley, W.G., Hanson, J.M. and Parmelee, R.A., "Behavior and Design of Prestressed Concrete Beams with Large Web Openings”, PCI Journal, Vol. 22, No. 6, Nov. Dec., 32-61,1977.

\section{تحسين أداء العتبات الخرساتية المسلحة الحاوية على فتحات واسعة في الجذع بواسطة خرسانة المساحيق المركبة :دراسة عملية المية الية

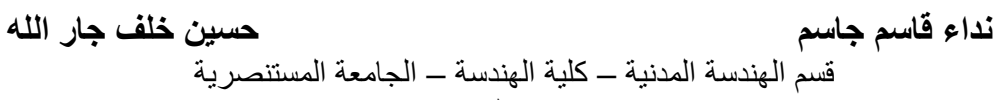 \\ بغداد - العراق}

khalfdce@uomustansiriyah.edu.iq

nidaaqj@gmail.com

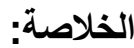

يقدم هذا البحث العملي دراسة سلوك العتبات الخرسانية مع الفتحات العريضة و المدعمة بخرسانة المساحيق المركبة بمواقع مختلفة

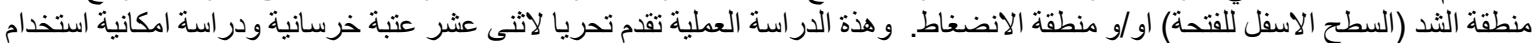

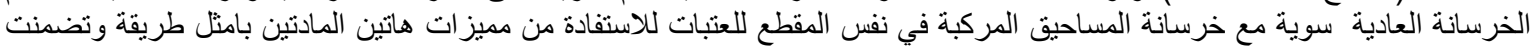

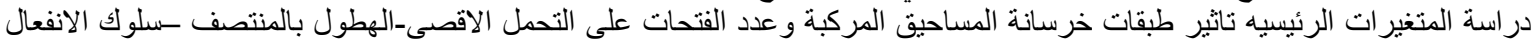

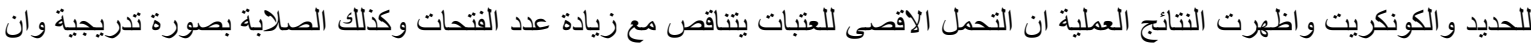

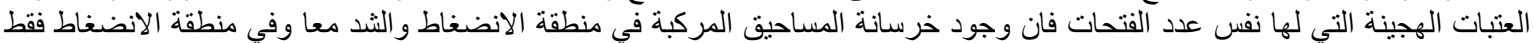

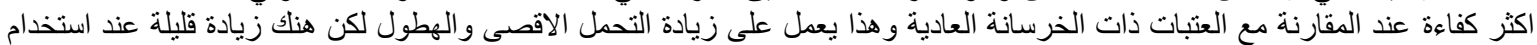

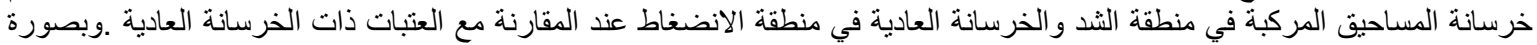

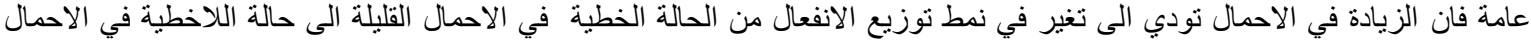

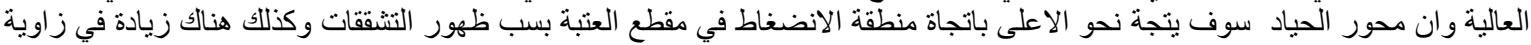

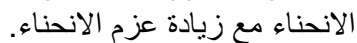
الكلمات الرئيسية: خرسانة المساحيق المركبة،فتحات،طبقات،/الهطول،/لانفعال،زاوية الانحناء،التثققات،مقطع هجين، المقاومة. 